\title{
UBEZPIECZENIE NIERUCHOMOŚCI Z CESJĄ PRAW JAKO ZABEZPIECZENIE SPŁATY KREDYTU HIPOTECZNEGO W KONTEKŚCIE INTERESU KONSUMENTA
}

Katarzyna Nowak

Instytut Finansów, Uniwersytet Ekonomiczny w Krakowie

\begin{abstract}
Streszczenie
Udzielanie kredytów przez banki obarczone jest ryzykiem kredytowym, jakim jest brak spłaty zobowiązania przez dłużnika. W tym celu banki wymagają zabezpieczeń, a jedną z głównych form zabezpieczenia kredytu jest ubezpieczenie, w szczególności ubezpieczenie nieruchomości od ognia i innych zdarzeń losowych. W praktyce banki wymagają również przeniesienia praw przyszłych przysługujących kredytobiorcy z umowy ubezpieczenia. Również kredytobiorcy narażeni są na różnego rodzaju ryzyka, których zmaterializowanie się może skutecznie utrudnić spłatę kredytu. W związku z tym, kredytobiorcy korzystają z ubezpieczeń w nadziei, że ubezpieczyciel pokryje dług w ramach ochrony ubezpieczeniowej. W artykule autorka przedstawia główne nieprawidłowości występujące $w$ praktyce $w$ dystrybucji ubezpieczeń nieruchomości od ognia i innych zdarzeń losowych oraz ocenia warunki cesji praw z umowy ubezpieczenia na bank.
\end{abstract}

Słowa kluczowe: kredyt, ubezpieczenie, zabezpieczenie kredytów.

JEL Class: G21, G22, D18. 


\section{WPROWADZENIE}

Bank przy udzielaniu kredytu hipotecznego wymaga od kredytobiorcy wykupienia licznych ubezpieczeń. Pomimo, że ubezpieczenie kredytu jest dla kredytobiorcy dobrowolne i regulacje ustawowe nie definiują go jako obligatoryjnego, to bank ma prawo wymagać ubezpieczenia przez cały okres trwania kredytu.

Jedną ze szczególnych form zabezpieczenia spłaty kredytu jest ubezpieczenie nieruchomości. Ubezpieczenie to jest wymagane przez banki jako obligatoryjne, ponieważ stanowi zabezpieczenie kredytowanej nieruchomości przed skutkami zdarzeń losowych. Od posiadania tego ubezpieczenia często uzależnione jest w ogóle uzyskanie kredytu hipotecznego przez kredytobiorcę.

Ubezpieczony $\mathrm{w}$ omawianym ubezpieczeniu jest chroniony na wypadek powstania szkody, która wpływa niekorzystnie na wartość zabezpieczenia kredytu. Bank poprzez cesję wierzytelności z umowy ubezpieczenia jest uprawnionym do otrzymania odszkodowania z tytułu zaistnienia wypadku ubezpieczeniowego (wystąpienia zdarzeń negatywnych) na stanowiącej zabezpieczenie kredytu nieruchomości. W związku z umową cesji praw to bank, a nie kredytobiorca podejmuje decyzję o sposobie wykorzystania środków z odszkodowania.

Produkt ubezpieczeniowy tego typu ogranicza również ryzyko kredytowe konsumenta. Konsument, który zaniecha spłacania kredytu z przyczyn losowych objętych ubezpieczeniem korzysta $\mathrm{z}$ ochrony ubezpieczeniowej a własność przedmiotu kredytowania pozostaje u kredytobiorcy. W rezultacie kredytodawca i kredytobiorca ponoszą znacznie mniejsze skutki wypadków losowych [Monkiewicz 2010: 352].

Autorka artykułu podejmuje próbę odpowiedzi na następujące pytania:

- czy ubezpieczenie nieruchomości chroni konsumenta przed ryzykiem utraty zdolności spłaty kredytu?

- czy konsument ma swobodę wyboru dowolnego ubezpieczyciela?

- na jakich warunkach jest wypłacane konsumentowi odszkodowanie $\mathrm{z}$ umowy ubezpieczenia?

Celem artykułu jest identyfikacja głównych nieprawidłowości występujących $\mathrm{w}$ dystrybucji ubezpieczeń nieruchomości przez banki oraz ocena warunków wypłaty odszkodowania przez ubezpieczyciela. Autorka stawia tezę, że cesja wierzytelności z umowy ubezpieczenia nieruchomości na bank przyczynia się do pogorszenia realności ochrony ubezpieczeniowej ze względu na utrudnioną procedurę uzyskania odszkodowania od ubezpieczyciela.

Artykuł został oparty na podstawie analizy literatury przedmiotu, jak i do analizy zostały wykorzystane otrzymane od banków oferty, w szczególności zapisy ogólnych warunków ubezpieczenia. 


\section{FORMY ZABEZPIECZENIA RYZYKA KREDYTOWEGO W KREDYCIE HIPOTECZNYM}

Instytucje finansowe, w tym banki prowadząc działalność, są nastawione na osiąganie zysku, a jednym ze sposobów, by go osiągnąć jest udzielanie kredytów. Kredyt jest obarczony ryzykiem, dlatego w celu minimalizacji tego ryzyka banki stosują różne formy zabezpieczeń.

Zabezpieczenie kredytu to rodzaj ochrony udzielonego przez bank zobowiązania kredytowego. Zgodnie z art. 93 ust. 1 ustawy Prawo bankowe [Ustawa z dnia 29 sierpnia 1997 r...., Dz.U. 2018, poz. 2187 ze zm.], (dalej jako PB) „W celu zabezpieczenia wierzytelności, które wynikają z czynności bankowych, bank może żądać od swoich dłużników zabezpieczenia przewidzianego w Kodeksie cywilnym i prawie wekslowym oraz zwyczajami przyjętymi w obrocie krajowym i zagranicznym". Artykuł ten wskazuje, że bank ma prawo wymagać zabezpieczenia w celu ograniczenia ryzyka kredytowego, jakim jest brak spłaty zobowiązania przez dłużnika. Zabezpieczenie to ma umożliwić wierzycielowi, czyli bankowi, zapewnienie zwrotu całej zaangażowanej przez bank kwoty wraz z należnymi odsetkami i prowizjami. Komentowany przepis nie zawiera w swojej treści ustawowej definicji pojęcia zabezpieczenia wierzytelności, dlatego można je rozumieć szeroko, jako każdy możliwy sposób umocnienia określonej wierzytelności bankowej.

Klasyfikacja rodzajów zabezpieczeń jest zróżnicowana i zależy od przyjętych kryteriów podziału. W literaturze przedmiotu najczęściej stosowana jest typologia na podstawie uwarunkowań prawnych. Prawne zabezpieczenia produktów finansowych dzieli się na dwa rodzaje: osobiste i rzeczowe. Zabezpieczenia osobiste kredytu charakteryzuje osobista odpowiedzialność kredytobiorcy, czyli osoby udzielającej zabezpieczenia. Kredytobiorca odpowiada wobec kredytodawcy całym swoim majątkiem, zarówno tym, który posiada w momencie zaciągania kredytu, jak i tym w którego posiadanie dopiero wejdzie [Dobosiewicz 2010: 88]. Przy takiej formie zabezpieczenia, w sytuacji braku spłaty zobowiązania, wierzyciel ma prawo do kapitału, który został zgromadzony przed, jak i po udzieleniu kredytu. Ten rodzaj zabezpieczenia stosowany jest przez banki w stosunku do konsumentów, którzy posiadają niewystarczającą zdolność kredytową. Do zabezpieczeń osobistych stosowanych przez banki przy kredycie zalicza się: poręczenie cywilne, poręczenie wekslowe (awal), weksel in blanco (gwarancja bankowa), cesje wierzytelności, przystąpienie do długu, przejęcie długu oraz pełnomocnictwo [Torzewska 2018].

Instytucje finansowe do powyższego zabezpieczenia osobistego mają prawo zażądać od kredytobiorcy również dokonania drugiego typu zabezpieczenia tj. rzeczowego. W zabezpieczeniach rzeczowych kredytu, odpowiedzialność osoby udzielającej zabezpieczenia ogranicza się do poszczególnych składników 
jej majątku. Do tego rodzaju zabezpieczeń mogą także zostać przypisane osoby trzecie, które nie pobierały żadnych korzyści związanych z zobowiązaniem. Zabezpieczeniami rzeczowymi kredytu są: hipoteka umowna, zastaw ogólny (zwykły), zastaw rejestrowy, przewłaszczenie na zabezpieczenie, kaucja bankowa, blokada środków na rachunku bankowym oraz ubezpieczenie kredytu [Torzewska 2018].

Banki wymagają od konsumentów (kredytobiorców) przede wszystkim zawarcia umowy ubezpieczenia, jako środka minimalizującego ryzyko związane ze spłatą kredytu [Więcko 2009: 19-35; Śmieja 2007: 193-214]. Dlatego przy kredytach hipotecznych oprócz wymaganego prawnego zabezpieczenia w postaci hipoteki banki zobowiązują kredytobiorcę do ustanowienia dodatkowego zabezpieczenia $\mathrm{w}$ postaci ubezpieczenia na życie i utraty pracy, ubezpieczenia nieruchomości stanowiącej przedmiot zabezpieczenia i przelewu wierzytelności z tytułu umowy ubezpieczenia na bank.

Umowę ubezpieczenia definiuje art. 805 Kodeksu cywilnego [Ustawa z dnia 23 kwietnia 1964 r..., Dz.U. 2019, poz. 1145 ze zm.], (dalej jako k.c.) w związ$\mathrm{ku} \mathrm{z}$ tym jest to umowa nazwana [Więcko-Tułowiecka 2014: 57]. Artykuł ten stanowi, że „przez umowę ubezpieczenia ubezpieczyciel zobowiązuje się w zakresie działalności swojego przedsiębiorstwa, spełnić określone świadczenie $\mathrm{w}$ razie zajścia przewidzianego $\mathrm{w}$ umowie wypadku, a ubezpieczający zobowiązuje się zapłacić składkę ubezpieczeniową". Umowa ubezpieczenia jest zgodnym oświadczeniem dwóch stron, czyli umową konsensualną [Więcko 2009: 19-35; Łuc 2010: 375]. Ma charakter dwustronnie zobowiązaniowy - ponieważ każda ze stron ma zobowiązanie wobec drugiej, jednostronnie kwalifikowany ponieważ jedną ze stron jest podmiot profesjonalny - ubezpieczyciel, który prowadzi swoją działalność za zezwoleniem organu nadzoru oraz odpłatny [Gnela 2013: 27-47; Szpunar 1997: 267]. O odpłatności umowy ubezpieczenia świadczy obowiązek ubezpieczającego do zapłaty składki na rzecz ubezpieczyciela [Dubis 2017]. Umowa ubezpieczenia to kontrakt najwyższego zaufania, którym powinny darzyć się nawzajem strony umowy [Krajewski 2004: 674]. Świadczenie ubezpieczyciela $\mathrm{w}$ razie zajścia przewidzianego $\mathrm{w}$ umowie zdarzenia polega na zapłacie w przypadku ubezpieczeń majątkowych odszkodowania.

Wybór formy zabezpieczenia należy do kompetencji banku, co wynika z treści art. 93 ust. 1 PB, jak i stosowanej praktyki bankowej. Formę zabezpieczenia kredytu bank ustala w porozumieniu z kredytobiorcą, biorąc pod uwage takie elementy jak: rodzaj kredytu, okres spłaty, stan majątkowy, status prawny kredytobiorcy [Szczukocka 2017: 145-156]. Jednak w myśl art. 69 ust. 2 pkt 6 PB instytucje bankowe są zobowiązane, aby sposób zabezpieczenia spłaty kredytu był określony w umowie kredytu hipotecznego.

Umowę ubezpieczenia mienia zawierają właściciele tego mienia, czyli kredytobiorcy z zamiarem ochrony przed skutkami ryzyka majątkowego, powodu- 
jącymi utratę, zniszczenie lub uszkodzenie mienia objętego ubezpieczeniem. Kredytobiorca zobowiązany jest otrzymane odszkodowanie przeznaczyć na odtworzenie (odbudowę, naprawę) uszkodzonej nieruchomości [Wieczorek-Kosmala 2018: 324-341]. Ubezpieczenie mienia zapewnia właścicielowi ubezpieczonej nieruchomości odszkodowanie, czyli świadczenie pieniężne, którego wysokość i zasady ustalania określa umowa lub ogólne warunki ubezpieczenia. Jednak w ubezpieczeniach majątkowych kwota wypłacona przez ubezpieczyciela $\mathrm{z}$ umowy ubezpieczenia może nie stanowić w pełni zwrotu kosztów poniesionych w celu przywrócenia stanu poprzedniego w majątku ubezpieczonego. W takim przypadku odszkodowanie nie odpowiada odszkodowaniu w rozumieniu art. $361 \S 1$ i 2 k.c.

\section{UBEZPIECZENIE NIERUCHOMOŚCI JAKO ZABEZPIECZENIE SPŁATY ZADŁUŻENIA}

Spośród licznych rodzajów ubezpieczeń stosowanych przez banki jako zabezpieczenia kredytu hipotecznego i zaliczanych do ubezpieczeń wymaganych jest ubezpieczenie nieruchomości. Ubezpieczenie nieruchomości należy do grupy ubezpieczeń majątkowych oferowanych w ramach współpracy banków z ubezpieczycielami [Nowak P. 2019: 57-67; Szaraniec 2015: 119-129]. Banki oferują ubezpieczenia $\mathrm{w}$ ramach sprzedaży łączonej wraz z innymi usługami bankowymi, szczególnie w umowie o kredyt.

Ubezpieczenie nieruchomości ma chronić konsumenta przed ryzykiem utraty zdolności spłaty kredytu, a kredytodawcę od ryzyka kredytowego, jakim jest brak spłaty zobowiązania przez dłużnika. Jeżeli nieruchomość jest ubezpieczona, a polisa jest sporządzona $\mathrm{z}$ cesją na bank, to - w przypadku zniszczenia nieruchomości - bank jako beneficjent otrzyma pieniądze z odszkodowania, które przeznaczy w pierwszej kolejności na pokrycie spłaty zadłużenia.

Ubezpieczenie nieruchomości do kredytu hipotecznego na rynku nazywane jest potocznie „ubezpieczeniem od ognia i innych zdarzeń losowych”. Ubezpieczenie ogniowe chroni przed zniszczeniem, uszkodzeniem lub utratą mienia w wyniku wystąpienia określonych zdarzeń ujętych w zakresie ochrony. Ubezpieczenie obowiązuje w przypadku szkody powstałej bezpośrednio na skutek zdarzenia losowego, które ma cechy: nagłego, przypadkowego i nieprzewidzianego zdarzenia i wymaga się, aby było niezależne od woli ubezpieczonego. Ubezpieczenie tego rodzaju obejmuje takie zdarzenia losowe, jak: ogień, powódź, huragan, eksplozja, deszcz nawalny, grad, lawina, zapadanie lub usuwanie się ziemi i innych zdarzeń, które powodują utratę lub znaczne zmniejszenie wartości nieruchomości [Strupczewski 2013: 146]. Nie znaczy to, że standardowa polisa ubezpieczenia nieruchomości zabezpiecza ją przed ryzykiem wystąpienia wszystkich zdarzeń losowych spowodowanych przez żywioły oraz tych wymie- 
nionych w grupie 8 i 9 załącznika do ustawy o działalności ubezpieczeniowej i reasekuracyjnej [Załącznik do ustawy z dnia 11 września 2015 r. podział ryzyka według działów, grup i rodzajów ubezpieczeń - dział II..., Dz.U. 2019, poz. 381 ze zm.]. Ubezpieczyciele dokładnie precyzują w warunkach umowy zdarzenia objęte ochroną oraz podają definicje stosowanych pojęć w ogólnych warunkach ubezpieczenia (OWU).

Przedmiot ubezpieczenia jest definiowany indywidualnie przez zakład ubezpieczeń, ale w podstawowych polisach ochronie podlegają następujące rodzaje nieruchomości: budynki mieszkalne, lokale mieszkalne i budynki mieszkalne w stadium budowy. W zależności od ubezpieczyciela, wraz z nieruchomością również objęte ochroną ubezpieczeniową mogą być: garaż, budowla, urządzenia budowlane związane $\mathrm{z}$ obiektem budowlanym oraz składowane na terenie posesji materiały budowlane.

Ubezpieczenia nieruchomości od ognia i innych zdarzeń losowych różnią się między sobą zakresem ubezpieczenia, czyli zdarzeniami, które wywołują odpowiedzialność odszkodowawczą. Zakres ubezpieczenia dobierany jest indywidualnie przez danego ubezpieczyciela i będzie różny w zależności od tego z jakim ubezpieczycielem zostanie zawarta umowa ubezpieczenia [Nowotarska-Romaniak i Ogrodnik 2015: 213-224]. Dla kredytobiorcy istotne jest, aby przed podjęciem decyzji o wyborze ubezpieczyciela sprawdzić zakres ochrony ubezpieczeniowej [Lewandowski 2006: 104]. Im zakres ubezpieczenia określony w ogólnych warunkach umowy jest szerszy, tym korzystniejszy dla konsumenta, bo zapewnia większą ochronę od różnego rodzaju ryzyk. Zakres ochrony powinien spełniać wymagania banku, ale przede wszystkim powinien być odpowiedni dla ubezpieczonego.

Odpowiedzialność ubezpieczyciela jest wyłączona w przypadku szkód powstałych wskutek umyślnego działania ubezpieczającego/ubezpieczonego, rażącego niedbalstwa i ich działań pod wpływem alkoholu i innych środków. Ponadto wyłączeniom mogą podlegać inne zdarzenia oraz niektóre rodzaje mienia, które są określone w OWU i skutkują brakiem wypłaty odszkodowania przez zakład ubezpieczeń.

Wybór sposobu ustalenia wartości przedmiotu ubezpieczenia jest zagadnieniem ważnym dla kredytobiorcy, bo wysokość sumy ubezpieczenia limituje odpowiedzialność ubezpieczyciela z tytułu wszelkich wypadków ubezpieczeniowych. Wybór zasady określenia sumy ubezpieczenia zależy od ubezpieczyciela i jest różny w zależności od przedmiotu podlegającego ochronie ubezpieczeniowej. Wyróżnia się dwa odmienne podejścia dla budynku mieszkalnego tj. według wartości odtworzeniowej, inaczej nowej, lub w wartości rzeczywistej, inaczej zwanej technicznej. Wybór jednej $\mathrm{z}$ dwóch powyższych metod uzależniony jest od wieku budynku mieszkalnego. Dla budynku, którego wiek jest mniejszy niż 30 lub 40 lat stosuje się wartość nową, a powyżej tego wieku war- 
tość techniczną. Z kolei w przypadku lokalu mieszkalnego jego wartość określa się na podstawie wartości rynkowej.

Każdy bank stosuje inne wymagania odnośnie określenia wartości sumy ubezpieczenia nieruchomości. Część banków wymaga ubezpieczenia nieruchomości na wartość zaciągniętego kredytu, a część na wartość nabytej nieruchomości. Dla kredytobiorców korzystne jest ubezpieczenie na pełną wartość nieruchomości niezależnie od wysokości zaciągniętego kredytu hipotecznego. Ubezpieczenie nieruchomości jedynie na wartość kredytu wiąże się z niedoubezpieczeniem nieruchomości. Skutkuje to tym, że w przypadku powstania szkody otrzymane odszkodowanie jest na niższym poziomie w stosunku do wartości nieruchomości. Wypłata odszkodowania przez ubezpieczyciela będzie ograniczona do wartości kwoty kredytu, ponieważ stanowi ona górną granicę odpowiedzialności zakładu ubezpieczeń. W celu uniknięcia niedoubezpieczenia w momencie wyboru konkretnego ubezpieczyciela należy sprawdzić, w jaki sposób jest określana wartość nieruchomości, a także jaka jest podana we wniosko-polisie [Wąsewicz 2011: 51-62].

Innym istotnym elementem dla kredytobiorcy w ubezpieczeniach nieruchomości jest wysokość składki. Składki ubezpieczeń zazwyczaj są naliczane od kwoty kredytu, a w niektórych bankach również od wartości rynkowej nieruchomości. Wartość składki obliczana jest według stosowanych przez ubezpieczycieli algorytmów. Średnia stawka ubezpieczenia może wynosić od $0,08 \%$ do $0,1 \%$ wartości ubezpieczanej w skali roku. Ubezpieczenie nieruchomości jest stosunkowo niedrogie w porównaniu do innych kosztów kredytu hipotecznego oraz pozostałych ubezpieczeń, ale w zależności od wybranych wariantów ochrony i sumy ubezpieczenia, okresu kredytowania składka ubezpieczeniowa może kształtować się na różnym poziomie. Cena ubezpieczenia jednak nie powinna być dla kredytobiorcy wyłącznym kryterium wyboru oferty ubezpieczeniowej. Kredytobiorca powinien dokonać wyboru takiego ubezpieczenia, które w jego opinii jest najlepiej dopasowane do jego potrzeb ubezpieczeniowych.

Ubezpieczenie kredytowanej nieruchomości, pomimo że należy do grupy ubezpieczeń nieobowiązkowych, dla banków jest ubezpieczeniem obligatoryjnym przy zawieraniu umowy kredytu hipotecznego. Obligatoryjność umowy ubezpieczenia wynika z zapisów ustawowych i zgodnie z art. 9 ust. 2 ustawy o kredycie hipotecznym oraz o nadzorze nad pośrednikami kredytu hipotecznego i agentami [Ustawa z dnia 23 marca 2017 r..., Dz.U. 2017, poz. 819 ze zm.] „kredytodawca może wymagać od konsumenta zawarcia lub posiadania umowy ubezpieczenia dotyczącej umowy o kredyt hipoteczny lub przelewu wierzytelności z tej umowy ubezpieczenia na kredytodawcę, informując jednocześnie konsumenta o możliwości wyboru oferty dowolnego ubezpieczyciela odpowiadającej minimalnemu zakresowi ubezpieczenia akceptowanemu przez kredytodawcę". 
Zgodnie z powyższą ustawą dano konsumentowi prawo wyboru dowolnego ubezpieczyciela pod warunkiem, że oferowane ubezpieczenie spełnia minimalny zakres ochrony akceptowany przez bank [Nierodka 2019; Paxford 2018]. W tej sytuacji bank ma obowiązek poinformować konsumenta zarówno o możliwości samodzielnego wyboru oferty ubezpieczenia, jak i przedstawić wymogi, jakie musi spełnić umowa ubezpieczenia (art. 9 ust. 3) aby kredytodawca ją zaakceptował. Regulacja ustawowa $\mathrm{w}$ tym zakresie jest zbieżna $\mathrm{z}$ wydaną przez KNF w 2014 r. Rekomendacją U [Rekomendacja U dotycząca dobrych praktyk w zakresie bancassurance, 2014, dostęp 10.05.2019], w której w punkcie 13 zaznaczono, że bank powinien zapewnić swobodę wyboru przez klienta zakładu ubezpieczeń, z którego klient zamierza skorzystać [Maśniak 2015: 221-232]. W tym celu bank zobowiązany jest przekazać klientowi minimalny zakres ochrony ubezpieczeniowej wystarczający dla zabezpieczenia roszczeń banku.

Umowa ubezpieczenia nieruchomości zawierana przez kredytobiorcę może być zawarta za pośrednictwem banku lub indywidualnie poza bankiem. Pierwsza opcja pozwala konsumentowi zaoszczędzić czas, ponieważ współpraca z bankiem pozwala na znaczne skrócenie procesu załatwiania formalności. Sposób ubezpieczenia nieruchomości indywidualnie jest zalecany świadomym konsumentom, którym zależy na wyborze jakości ubezpieczenia. W przypadku wyboru ubezpieczenia nieruchomości we własnym zakresie, konsument może uzyskać lepszą polisę majątkową, np. na szerszy zakres objętych ochroną zdarzeń losowych lub obniżyć koszty tego ubezpieczenia, bo ma możliwość wynegocjowania niższej składki.

W świetle powyższych przepisów prawa, banki wywiązują się z obowiązków informacyjnych o możliwości samodzielnego wyboru oferty ubezpieczenia u dowolnego ubezpieczyciela przez konsumenta. Skorzystanie z tego przepisu przez konsumenta nie jest już takie jednoznaczne i pewne. W rzeczywistości konsument zawsze może udać się do innego zakładu ubezpieczeń, ale musi liczyć się z tym, że bank u którego stara się o kredyt może podnieść mu koszt (cenę) kredytu. Pomimo, że banki spełniają wymóg informacyjny i informują klienta o jego prawie wyboru dobrowolnego ubezpieczyciela, to nadal występują $\mathrm{w}$ tej materii liczne nieprawidłowości utrudniające dokonanie tego wyboru.

Jedną z głównych nieprawidłowości występujących w praktyce bankowej jest podwyższanie marży, w sytuacji gdy kredytobiorca zwróci się o ochronę ubezpieczeniową do innego zakładu ubezpieczeń niż ten, który współpracuje $\mathrm{z}$ bankiem. Podwyższenie marży w takim przypadku pomimo faktu, iż nie jest to ustawowo zakazane, może skutecznie zniechęcić kredytobiorcę do poszukiwania ochrony ubezpieczeniowej u innego ubezpieczyciela. Takie praktyki przyczyniają się do wzrostu całkowitego kosztu kredytu, przez co kredyt staje się dla konsumenta droższy. 
Innym zastrzeżeniem wobec banków jest wymaganie od konsumenta zawarcia umowy ubezpieczenia za pośrednictwem banku na pierwsze 3-4 lata trwania kredytu, a dopiero po upływie tego okresu klient może skorzystać z oferty innego zakładu ubezpieczeń.

Zidentyfikowane powyżej nieprawidłowości zagrażają interesom pojedynczych konsumentów [Nowak P. 2018: 199-209]. W przypadku podjęcia decyzji o ubezpieczeniu kredytu konsument powinien wnikliwie zapoznać się z warunkami umowy ubezpieczenia. Ubezpieczenie nieruchomości do kredytu hipotecznego przez potencjalnego konsumenta - kredytobiorcę zazwyczaj nie jest dostatecznie analizowane pod względem przedmiotu i zakresu ochrony czy wartości sumy ubezpieczenia i innych warunków, a nawet pomijane. Zapewne wynika to $\mathrm{z}$ faktu, że ubezpieczenie nieruchomości jest obowiązkowe w każdym banku i stanowi jeden z niższych kosztów w kalkulacji ceny kredytu hipotecznego.

Wybór ubezpieczenia nieruchomości, której zakup finansowany jest przy pomocy kredytu hipotecznego nie jest łatwy ze względu na skomplikowany charakter czy trudny do zrozumienia język umów [Nowak K. 2019: 68-82]. Ważne jest jednak, by kredytobiorca przy wyborze ubezpieczenia dobrze przeanalizował różne warianty, które pozwolą mu uniknąć błędów, ale przede wszystkim ułatwią mu wybór właściwej dla siebie opcji. Popełnione błędy przez kredytobiorcę na etapie zawierania umowy ubezpieczeniowej mogą być dla niego krytyczne i skutkować nawet brakiem wypłaty odszkodowania.

\section{CESJA WIERZYTELNOŚCI Z UMOWY UBEZPIECZENIA}

Zabezpieczenie spłaty kredytu umową ubezpieczenia mienia polega na dokonaniu cesji praw przysługujących ubezpieczonemu na bank, który udziela kredytu. Przy zawieraniu umowy ubezpieczenia nieruchomości przez kredytobiorcę banki, w celu posiadania gwarancji spłaty kredytu, żądają cesji praw z polisy ubezpieczeniowej. Bez wątpienia umowa ta służy ochronie wierzytelności banków i ma na celu zabezpieczenie spłaty kredytu $\mathrm{w}$ razie zajścia przewidzianego w umowie zdarzenia losowego [Pokrzywniak 2008: 104; Gruszczyński 2018: 43-61]. Co do zasady przeniesienie praw z umowy ubezpieczenia powoduje również przeniesienie obowiązków wynikających $\mathrm{z}$ tej umowy [Szydłowska 2018: 51-67]. Bank, aby być zwolnionym z obowiązku zapłaty składki ubezpieczeniowej zastrzega w umowie cesji, że to cedent (kredytobiorca) jest zobowiązany do spełniania wszystkich warunków stawianych przez ubezpieczyciela dla zachowania ważności umowy ubezpieczenia, a więc między innymi terminowego opłacania składki.

Wypłata świadczenia następuje na rzecz banku na podstawie umowy cesji wierzytelności z umowy ubezpieczenia nieruchomości. Zabezpieczenie spłaty 
kredytu umową ubezpieczenia mienia polega na dokonaniu cesji praw przyszłych przysługujących ubezpieczonemu z tytułu umowy ubezpieczenia na bank, który kredytuje ubezpieczoną nieruchomość. Cesja praw z umowy ubezpieczenia oznacza, że poszkodowany, czyli kredytobiorca, w przypadku zaistnienia wypadku ubezpieczeniowego nie otrzyma odszkodowania, choć zgodnie z kodeksem cywilnym kwota odszkodowania powinna być wypłacona przez zakład ubezpieczeń osobie, która poniosła szkodę. Odszkodowanie ma zrekompensować poniesione przez poszkodowanego straty. W okresie obowiązywania umowy jedynym uprawnionym do otrzymania odszkodowania z tytułu umowy ubezpieczenia jest bank, który przeznacza otrzymane odszkodowanie na spłatę długu kredytobiorcy, a dopiero w przypadku ewentualnej nadwyżki zwraca ją cedentowi.

W umowie cesji zastrzega się, że to bank podejmie decyzję o sposobie wykorzystania środków z odszkodowania. Istnieje możliwość, że na wniosek kredytobiorcy bank może zlecić ubezpieczycielowi wypłatę odszkodowania cedentowi w celu przywrócenia przedmiotu ubezpieczenia do stanu poprzedniego. Jeżeli takiego zezwolenia nie otrzyma, cedent jest zobowiązany do usunięcia szkody na własny koszt $\mathrm{w}$ terminie wyznaczonym przez bank. W przypadku całkowitego zniszczenia nieruchomości, jeżeli cedent nie złoży powyższego wniosku, to kwota odszkodowania automatycznie zostaje przeznaczona na spłatę zadłużenia konsumenta.

Warunki, jakie konsument musi spełnić, aby odszkodowanie zostało mu wypłacone, są zawarte w umowie cesji. Niektóre banki wypłacają odszkodowanie tylko rzetelnemu kredytobiorcy, a inne uzależnią wypłatę od wysokości odszkodowania. W związku z tym istotne jest, aby konsument mógł zapoznać się z umową cesji i jej warunkami, np. wypłaty odszkodowania jeszcze przed podpisaniem umowy kredytowej. Niestety nie każdy bank udostępnia wzór umowy cesji, w związku z tym zapoznanie się z umową i porównanie warunków cesji oferowanych przez różne banki jest utrudnione.

Kredytobiorca podpisując umowę cesji zrzeka się z wszelkich roszczeń od ubezpieczyciela i prawa do otrzymania odszkodowania, które mógłby przeznaczyć na usunięcie szkody powstałej w wyniku zdarzenia. Kredytobiorca, który nie otrzyma od ubezpieczyciela odszkodowania, a więc kwoty na naprawienie szkody i nie posiada środków własnych na jej naprawienie może mieć problem $\mathrm{z}$ doprowadzeniem mienia do stanu sprzed szkody, co negatywnie wpłynie na wartość nieruchomości.

Co prawda, w przypadku wypłaty odszkodowania z tytułu szkody na nieruchomości, kwota ta zazwyczaj zmniejsza zobowiązanie kredytobiorcy wobec banku, ale przecież nie to jest głównym celem ubezpieczenia. Celem ubezpieczenia jest ochrona nieruchomości, która również stanowi zabezpieczenie spłaty kredytu. W związku z tym, przeznaczenie wypłaty odszkodowania powinno zależeć od potrzeb kredytobiorcy, który powinien sam lub w porozumieniu 
z bankiem zadecydować na co przeznaczyć odszkodowanie. Umowa ubezpieczenia nieruchomości powinna stanowić lepszą ochronę interesów konsumenta, który przecież ponosi koszty ubezpieczenia.

\section{PODSUMOWANIE}

Umowa ubezpieczenia nieruchomości zabezpiecza w szczególności bank, ale również i konsumenta, jednakże tylko w zakresie spłaty długu. Bank wymaga tego ubezpieczenia $\mathrm{w}$ minimalnym zakresie ochrony, dlatego ubezpieczenie to nie jest drogie, a chroni kredytobiorcę przed poważnym ryzykiem wystąpienia wypadku ubezpieczeniowego oraz daje mu poczucie bezpieczeństwa. Niejednokrotnie świadomość tego, że w przypadku nieprzewidzianych zdarzeń losowych część lub całość kredytu zostanie spłacona z polisy jest warta poniesienia kosztów związanych z ubezpieczeniem kredytu.

W ocenie autorki ubezpieczenie od „ognia” dystrybuowane przez banki nie uwzględnia wszystkich potrzeb klienta. W związku z tym, nie jest ono w pełni dopasowane i zindywidualizowane. Pomimo, że w większości są to ubezpieczenia jednostkowe (indywidualne), to jednak odgórnie określony zakres ochrony jest taki sam dla wielu ubezpieczonych (kredytobiorców).

Również zapisy umowy cesji autorka ocenia jako niekorzystne dla kredytobiorcy. Odszkodowanie powinien otrzymać podmiot, który poniósł stratę na nieruchomości, czyli kredytobiorca a nie bank, który tak naprawdę szkody nie poniósł. Powyższą ocenę potwierdza również fakt, że nieruchomość jest zabezpieczeniem kredytu (hipoteka) i dlatego podtrzymanie jej wartości powinno być istotne zarówno dla konsumenta, jak i dla banku.

Łatwy dostęp do kredytów sprawia, że ubezpieczenia kredytów cieszą się dużym zainteresowaniem i są często stosowaną formą zabezpieczenia spłaty kredytu [Szczukocka 2017: 145-156]. Nie bez znaczenia jest świadomość konsumenta podczas zawierania umowy ubezpieczenia nieruchomości, gdy zapoznaje się $\mathrm{z}$ warunkami i wyłączeniami ochrony oraz zasadami cesji praw z umowy ubezpieczenia. Tylko rzeczywista ocena $\mathrm{i}$ świadomie podejmowane decyzje przez konsumenta przy wyborze ubezpieczenia mogą przyczynić się do wzrostu adekwatności ochrony ubezpieczeniowej. 


\section{BIBLIOGRAFIA}

Dobosiewicz Z., 2010, Kredyt hipoteczny. Poradnik, Difin, Warszawa.

Dubis W., 2017, Komentarz do art. 805 Kodeksu cywilnego, [w:] E. Gniewek, P. Michnikowski, Kodeks cywilny. Komentarz, C.H. Beck.

Gnela B., 2013, Konsumencki a ubezpieczeniowy rezim ochrony podmiotów stosunku ubezpieczenia, [w:] B. Gnela, M. Szaraniec (red.), Kierunki rozwoju ubezpieczeń gospodarczych w Polsce. Wybrane zagadnienia prawne, Difin, Warszawa.

Gruszczyński A., 2018, Przeniesienie wierzytelności z umowy ubezpieczenia majątkowego, „Wiadomości ubezpieczeniowe", $\mathrm{nr} 2$.

Monkiewicz J., 2010, Ubezpieczenia na rynku finansowym, [w:] J. Handschke, J. Monkiewicz (red.), Ubezpieczenia. Podręcznik akademicki, Wydawnictwo Poltext, Warszawa.

Krajewski M., 2004, Umowa ubezpieczenia. Art. 805-834 KC. Komentarz, C.H. Beck, Warszawa.

Lewandowski K., 2006, Ubezpieczenie nieruchomości, Wydawnictwo Prawnicze LexisNexis, Warszawa.

Łuc M., 2010, Umowy o ustugi finansowe w sektorze ubezpieczeniowym, [w:] F. Grzegorczyk, M. Szaraniec, Instytucje i ustugi finansowe, LexisNexis, Warszawa.

Maśniak D., 2015, Doinformowanie czy przeciażenie informacyjne $w$ stosunku bancassurance, czyli o zakresie informowania ubezpieczonych, [w:] B. Gnela, M. Szaraniec, Informacja w prawie ubezpieczeń gospodarczych, Wolters Kluwer, Warszawa.

Nierodka A., 2019, Komentarz do art. 9 ustawy o kredycie hipotecznym oraz o nadzorze nad pośrednikami kredytu hipotecznego i agentami, [w:] I. Heropolitańska, A. Nierodka, Ustawa o kredycie hipotecznym oraz o nadzorze nad pośrednikami kredytu hipotecznego i agentami. Komentarz. Wolters Kluwer.

Nowak K., 2019, Dostep konsumenta do informacji w procesie kredytowym, [w:] B. Gnela, E. Sługocka-Krupa, M. Szaraniec, A. Viglianisi Ferraro, Prawo konsumenckie w Polsce oraz innych wybranych państwach UE. Zagadnienia wybrane, C.H. Beck, Warszawa.

Nowak P., 2018, Ocena zdolności kredytowej jako narzędzie ochrony konsumenta, [w:] M. Jagielska, K. Podgórski, E. Sługocka-Krupa, M. Fras, Prawa konsumenta $w$ teorii i praktyce, C.H.Beck, Warszawa.

Nowak P., 2019, Ubezpieczenie kredytu gotówkowego - korzyści dla kredytobiorcy czy kredytodawcy, [w:] B. Gnela, E. Sługocka-Krupa, M. Szaraniec, A. Viglianisi Ferraro, Prawo konsumenckie $w$ Polsce oraz innych wybranych państwach UE. Zagadnienia wybrane, C.H. Beck, Warszawa.

Nowotarska-Romaniak B., Ogrodnik H., 2015, Ubezpieczenia mieszkaniowe. Konstrukcja, decyzje zakupu, [w:] W. Sułkowska, G. Strupczewski, Dylematy teorii i praktyki ubezpieczeń, Poltext, Warszawa.

Paxford B., 2018, Art. 9 ustawy o kredycie hipotecznym oraz o nadzorze nad pośrednikami kredytu hipotecznego i agentami, [w:] B. Paxford, Ustawa o kredycie hipotecznym oraz o nadzorze nad pośrednikami kredytu hipotecznego i agentami. Komentarz. C.H. Beck.

Pokrzywniak J., 2018, Komentarz do niektórych przepisów Kodeksu cywilnego, [w:] M. Orlicki, J. Pokrzywniak, Umowa ubezpieczenia. Komentarz do nowelizacji kodeksu cywilnego, Wolters Kluwer, Warszawa.

Rekomendacja $U$ dotyczaca dobrych praktyk $w$ zakresie bancassurance, 2014, Urząd Komisji Nadzoru Finansowego, Warszawa.

Strupczewski G., 2013, Charakterystyka wybranych ubezpieczeń majątkowych, [w:] W. Sułkowska, Współczesne ubezpieczenia gospodarcze, Wydawnictwo Uniwersytetu Ekonomicznego w Krakowie, Kraków. 
Szaraniec M., 2015, Rezimy ochronne ubezpieczonego w umowie ubezpieczenia na cudzy rachunek, [w:] B. Gnela, K. Michałowska, Współczesne wyzwania prawa konsumenckiego, C.H. Beck, Warszawa.

Szczukocka A., 2017, Ubezpieczenie jako forma zabezpieczenia kredytu, Wydawnictwo Uniwersytetu Łódzkiego, Łódź.

Szpunar A., 1997, Zabezpieczenia osobiste wierzytelności, Wydawnictwo prawnicze Lex, Sopot.

Szydłowska N., 2018, Bank jako uprawniony do dochodzenia roszczeń z umowy ubezpieczenia zawartej jako zabezpieczenie spłaty kredytu, „Wiadomości ubezpieczeniowe”, $\mathrm{nr} 3$.

Śmieja A., 2007, Z problematyki przeniesienia praw w celu zabezpieczenia wierzytelności (przegląd możliwości), [w:] B. Gnela, Ochrona konsumenta ustug finansowych. Wybrane zagadnienia prawne, Wolters Kluwer Polska, Warszawa.

Torzewska I., 2018, Ubezpieczenia kredytu hipotecznego, KNF, CEDUR, Warszawa.

Ustawa z dnia 23 kwietnia 1964 r., Kodeks cywilny, (t.j. Dz.U. 2019, poz. 1145 ze zm.).

Ustawa z dnia 23 marca 2017 r. o kredycie hipotecznym oraz o nadzorze nad pośrednikami kredytu hipotecznego i agentami (Dz.U. 2017, poz. 819 ze zm.).

Ustawa z dnia 29 sierpnia1997 r. Prawo bankowe (t.j. Dz.U. 2018, poz. 2187 ze zm.).

Wąsewicz M., 2011, Ubezpieczenie jako instrument zmniejszający ryzyko w procesie zarzadzania nieruchomościami, [w:] W. Sułkowska, Ubezpieczenia gospodarcze i społeczne. Wybrane zagadnienia ekonomiczne, Wolters Kluwer business, Warszawa.

Wieczorek-Kosmala M., 2018, Ubezpieczenie mienia, [w:] M. Iwanowicz-Drozdowska, Ubezpieczenia, PWE, Warszawa.

Więcko M., 2009, Umowa ubezpieczenia jako zabezpieczenie wierzytelności banku - analiza podstaw prawnych, teorii i praktyki, ,Rozprawy Ubezpieczeniowe”, $\mathrm{nr} 7$.

Więcko-Tułowiecka M., 2014, Ochrona konsumentów w umowach ubezpieczenia, Lexis Nexis, Warszawa.

Załącznik do ustawy z dnia 11 września 2015 r. podział ryzyka według działów, grup i rodzajów ubezpieczeń - dział II. Ustawa z dnia 11 września 2015 r. o działalności ubezpieczeniowej i reasekuracyjnej (t.j. Dz.U. 2019, poz. 381 ze zm.).

\title{
INSURANCE OF REAL ESTATE WITH ASSIGNMENT OF RIGHTS AS A SECURITY FOR MORTGAGE LOAN REPAYMENT IN THE CONTEXT OF INTERESTS OF CONSUMERS
}

\begin{abstract}
Lending by banks is fraught with credit risk which can be defined as a risk of default of the borrower. For this purpose banks require collateral especially insurance specifically insurance of real estate. Borrowers are also exposed to various types of risks which may make difficult to repay the loan in the future. In this connection borrowers can also benefit from insurance in the hope that insurer will repay the debt within insurance protection. In the article author presents the impropriety occurring in practice at the insurance of real estate distribution and assesses the main conditions assignment of rights to the bank.
\end{abstract}

Keywords: credit, collateral of loans, insurance. 